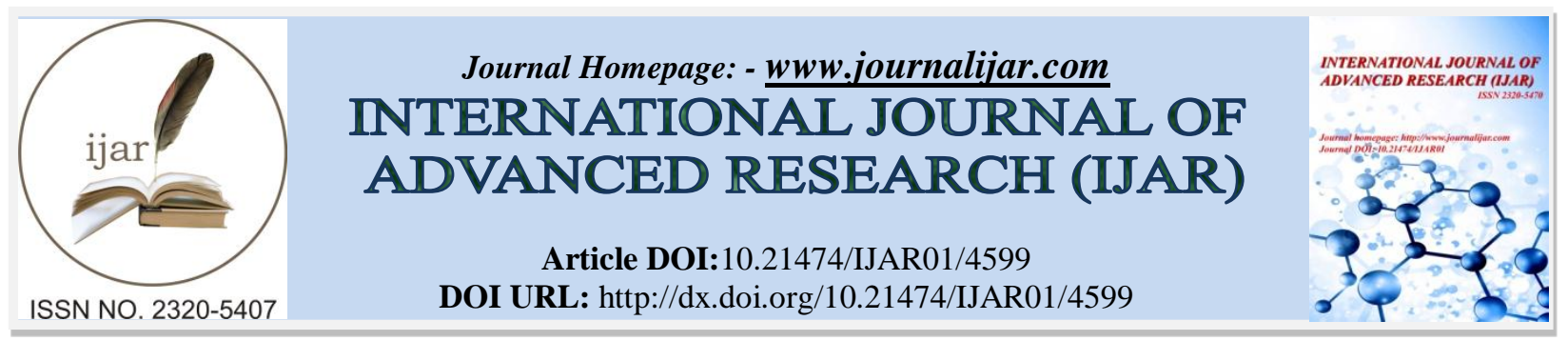

RESEARCH ARTICLE

\title{
A CASE REPORT OF ODONTOGENIC KERATOCYST IN ANTERIOR MANDIBLE.
}

\author{
Dr. Moin Iftikhar Shapoo ${ }^{1}$, Prof. Dr. Nitin Jaggi ${ }^{2}$, Prof. Dr. Ashish Singh ${ }^{3}$ Dr. Nikhil Purohit ${ }^{4}$ and Dr. Udit \\ Prakash ${ }^{1}$. \\ PG Student 2.HOD 3.Professor 4.Reader, Maharana Pratap College Of Dentistry and Research Centre, Gwalior.
}

\section{Manuscript Info}

\section{Manuscript History}

Received: 24 April 2017

Final Accepted: 26 May 2017

Published: June 2017

Key words:-

Odontogenic Cysts, Odontogenic

Keratocyst, Jaw Cysts, Mandible, Cysts

\section{Abstract}

Odontogenic keratocyst (OKC) is a common developmental odontogenic cyst affecting the maxillofacial region that arises from the dental lamina. The OKC is distinctive among jaw cysts given its tendency toward recurrence and aggressive clinical behavior. This article presents a case of OKC in the anterior.

Copy Right, IJAR, 2017,. All rights reserved.

\section{Introduction:-}

Odontogenic keratocyst was first explained by Phillipsen in $1956^{[1]}$. It is one of the most aggressive odontogenic cysts of the oral cavity. OKC is known for its rapid growth and its tendency to invade the adjacent tissues including bone. According to latest World Health Organization (WHO) classification, OKC is termed like tumor because it has neoplastic nature. It is a benign tumor with many diagnosing clinical and histopathological views. It has locally destructive behavior (extension more than expansion), high recurrence rate and association with nevoid basal cell carcinoma syndrome or "Gorlin syndrome" ${ }^{[2,3]}$. KeratoCystic Odontogenic Tumor(KCOT) in the jaws arise from the cell rests of dental lamina and are usually seen during the second to fourth decades of life with a slight male predilection. The majority of patients are in the age ranges of 20-29 and 40-59 years, ${ }^{[4]}$ but cases ranging from 5 to 80 years have been reported. ${ }^{[5]} \mathrm{A}$ total of $70 \%$ to $80 \%$ keratocysts are most commonly found in the lower jaw in the angle between jaw and mandibular branch and in the maxilla in the area of the third molar. ${ }^{[1,6]}$ Growth is chiefly in the anteroposterior dimension, and the lesions may attain remarkable size without significantly deforming the jaw skeleton. The particular tendency to rapid growth is due to the higher activity of the epithelial cells of the cyst lining, stimulating osteolytic activity ofprostaglandin substances in the cell population of the cyst lining and the higher accumulation of hyperkeratotic scales in the lumen of the cyst, resulting in greater difference in hydrostatic pressure.

\section{Case Report:-}

A 20-year-old male patient reported to the Department of Oral and Maxillofacial Surgery, Maharana Pratap College of Dentistry and Research Centre, Gwalior, with the chief complaint of swelling and pain in the chin region from the past 4 months. Patient's general condition was normal. On extraoral examination, a diffuse swelling was noted in the lower jaw region extending right side of the parasymphysis to the left side. The swelling was soft, fluctuant, tender on palpation. On intraoral examination, there was a diffuse swelling extending from distal surface of 35 to the distal surface of 45 with the obliteration of the vestibule. 
Panoramic radiograph revealed multilocular radiolucent area extending from 34 to 43 region with well-demarcated borders. Thinning of cortical bone along with cortical expansion in mid-symphysis region was noted.

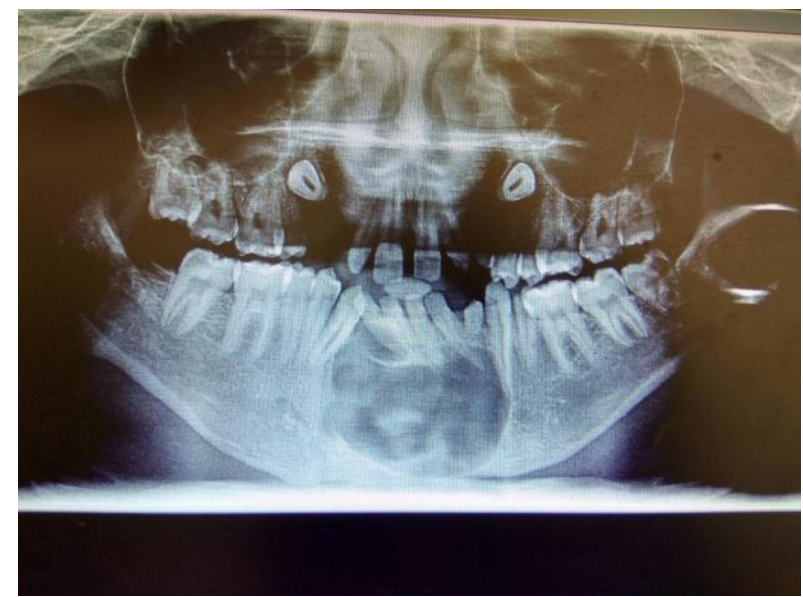

Fig 1:- OPG revealing multilocular radiolucent area.

Fine Needle Aspiration Cytology (FNAC) was performed using 24-gauge needle attached to a 10-ml syringe. Aspirate was creamy white suspension with keratin flakes. Smears showed scattered mature and degenerated squamous cells and rare inflammatory cells in a necrotic background.

\section{Procedure:-}

Under General Anesthesia, through intraoral incision, the mass was exposed. Enucleation of the lesion and extraction of the involved teeth were accomplished. Soft tissues adhering to the capsule of the lesion in the buccal fenestration were also removed. Then, peripheral ostectomy of the whole surgical bed was completed, followed by a single application of Carnoy's solution. The thinned out inner cortical lining of the bone was removed. The lesion contained white, cheesy material. The multilocular cystic lesion was sent for histopathologic examination.

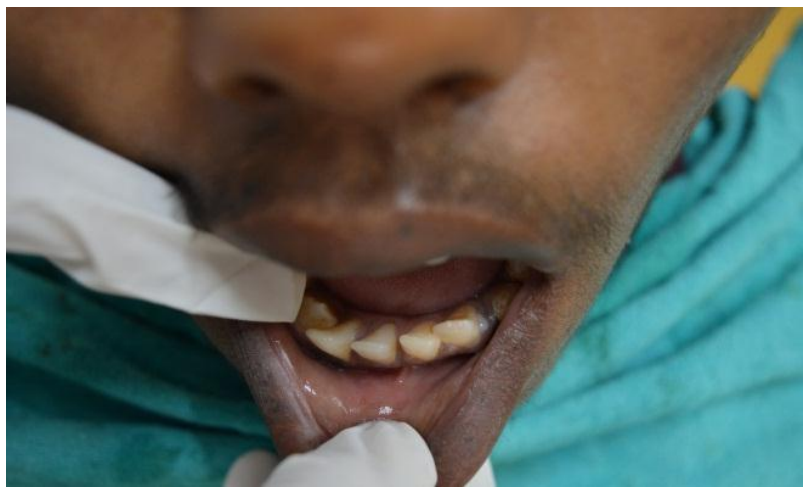

Fig 2:- Intraoral examination showing diffuse swelling extending from distal surface of 34 to the distal surface of 43 with the obliteration of the vestibule

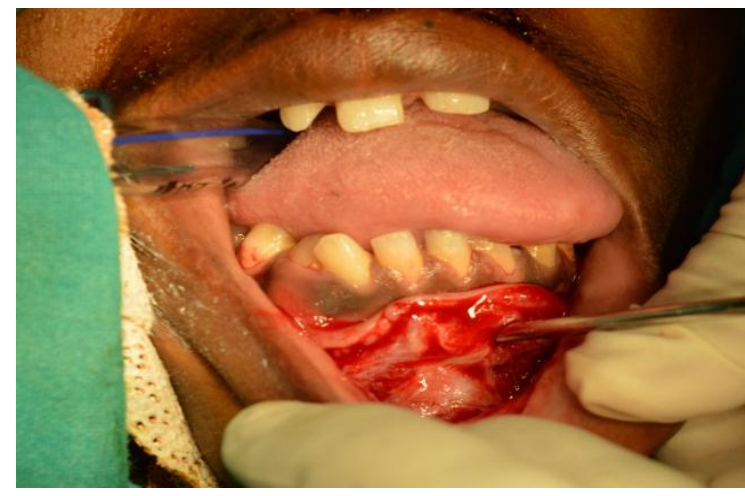

Fig 3:-Intraoral incision given to expose the mass 


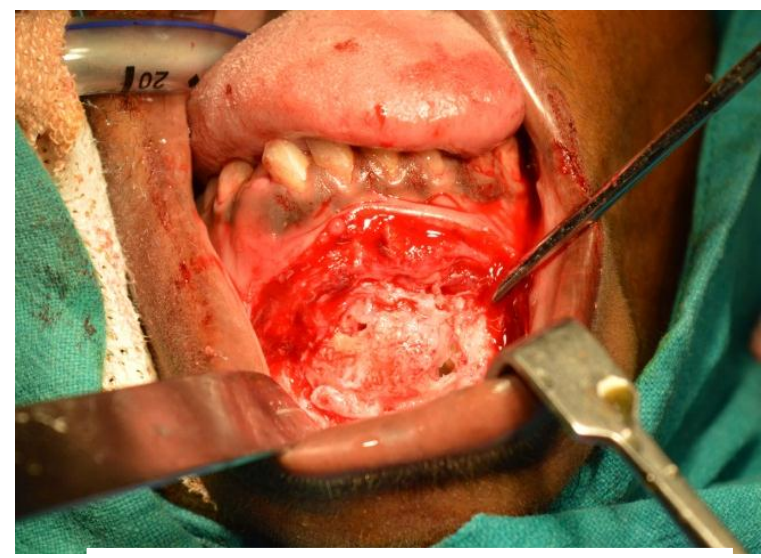

Fig 4:- Showing the exposed site

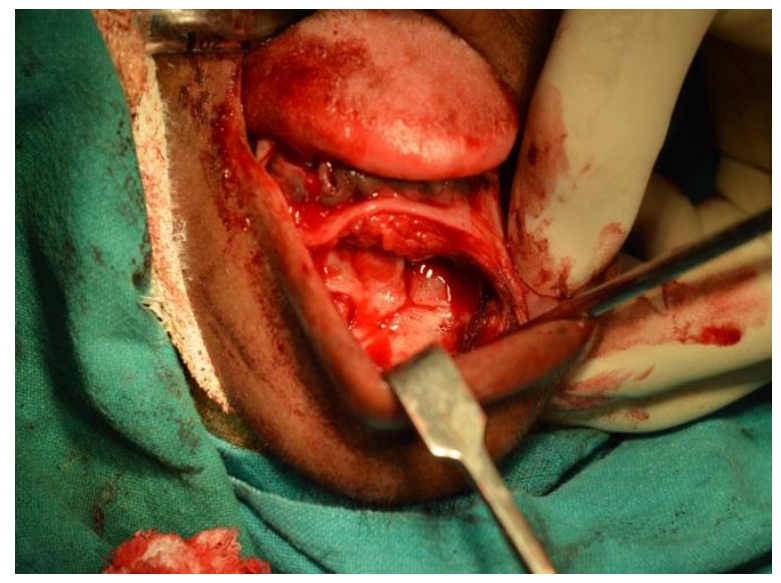

Fig 7:- Showing the clear cavity after the enucleation.

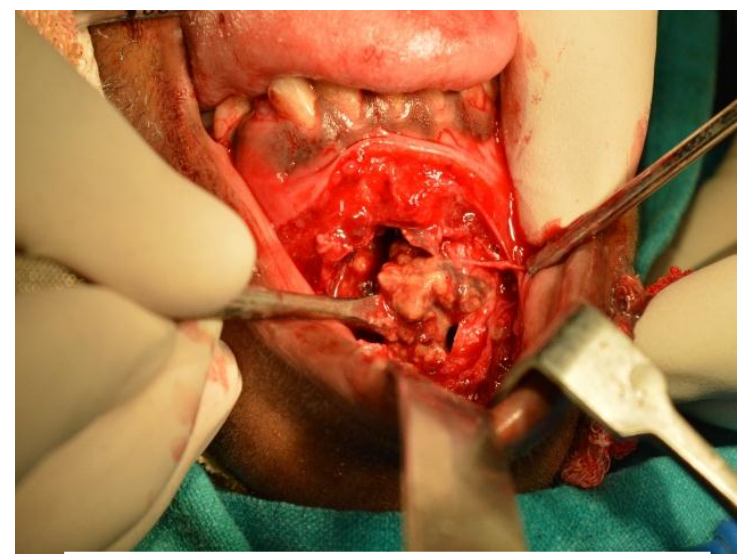

Fig6:-Enucleation of the lesion

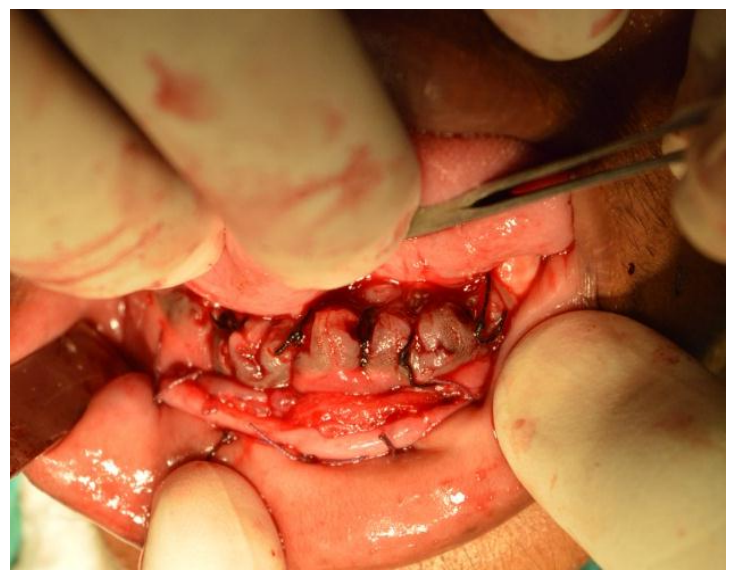

Fig 8:- Post Operative

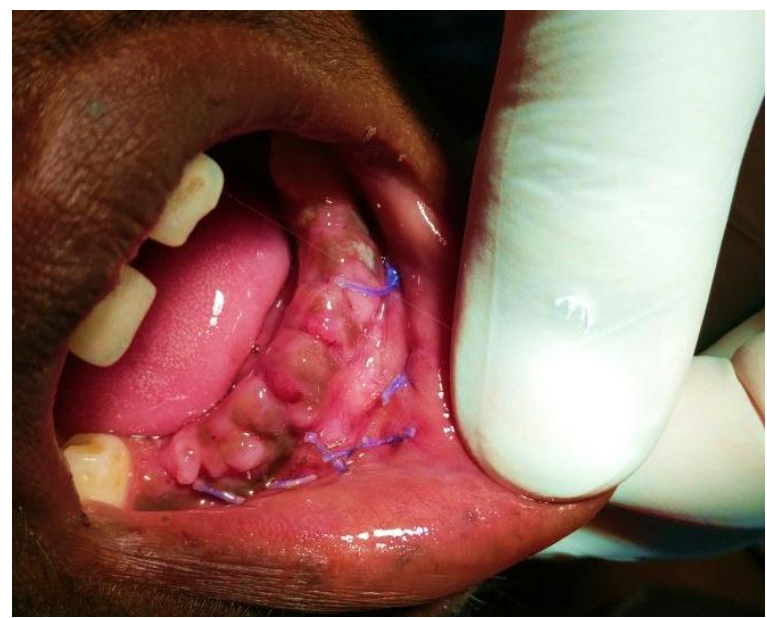

Fig 9:- One week postoperative follow up

Histopathologic evaluation revealed cystic lining with hyperplastic squamous cell with mild hyperparakeratosis and acanthosis. Stroma was congested with focal inflammatory cell infiltration. 


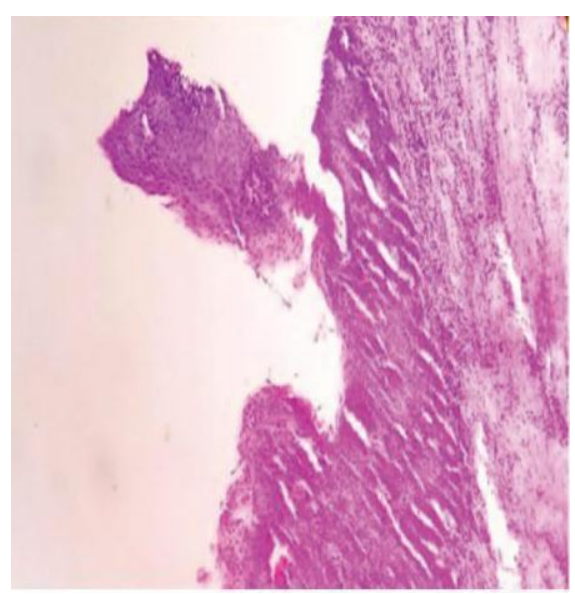

Fig 9:-Histopathological slide revealing cystic lining with hyperplastic squamous cell with mild hyperparakeratosis and acanthosis

\section{Discussion:-}

$\mathrm{OKC}$ is a common developmental odontogenic cyst, and its biologic behavior is similar to a benign neoplasm. ${ }^{\text {[7] }}$ Therefore, in the latest WHO classification of odontogenic tumors in 2005, it has been given the term keratocystic odontogenic tumor. ${ }^{[8]}$ OKCs are generally thought to be derived from either the epithelial remnants of the tooth germ or the basal cell layer of the surface epithelium. ${ }^{[9,10]}$.

KCOT may be found in any age, with peak the prevalence between the age 10 and 40 years. ${ }^{[10]}$ The mandible is involved in $60 \%$ to $80 \%$ of cases with a marked tendency to occur in the posterior body and ascending ramus. ${ }^{[11]}$ However in this case, the lesion was present in anterior mandible associated with impacted canine and involving contralateral jaw bone. Small OKCs are usually asymptomatic, but larger ones may show clinical manifestations such as pain, swelling, or drainage. ${ }^{[12]}$

Radiologically, KCOTs demonstrate a well-defined radiolucent area with smooth and often corticated margins and may be unilocular or multilocular. In $25 \%$ to $40 \%$ of cases, an unerupted tooth is seen in association with the lesion. ${ }^{[1]}$ The diagnosis of $\mathrm{OKC}$ is based on the histopathologic features. The radiographic findings, although often highly suggestive, are not diagnostic

Therapeutic interventions of KCOT include marsupialization and enucleation, combined with adjuvant cryotherapy with Carnoy's solution, and marginal or radical resection. ${ }^{[9]}$ OKCs/ KCOTs are characterized by high tendency to postoperative recurrence $(30 \%-60 \%)$. Causes of high recurrence rates include incomplete removal, remnants of dental lamina, and presence of daughter/satellite cysts within the cyst wall. ${ }^{[13]}$ Because recurrence may be long delayed in this lesion, follow up of any case of $\mathrm{OKC}$ with annual radiographs is essential for at least 5 years after the surgery.

\section{References:-}

1. Philipsen HP. Om keratocyster (kolesteatom) I kaekberne. Tandlaegegebladet 1956;60:963-81.

2. White S.C, Pharoah M.J. Oral Radiology Principles and Interpretation. 6th ed, Elsevier, Philadelphia, 2009, Chapter 21; 351-353.

3. Wood N.K, Goas P.W. Differential diagnosis of oral and maxillofacial lesions. 5th ed, Elsevier, Philadelphia, 1997, Chapter 17; 280-288.

4. Brondum N, Jensen VJ. Recurrence of keratocysts and decompression treatment. A long-term follow-up of forty-four cases. Oral Surg Oral Med Oral Pathol 1991;72:265-69.

5. Haring JI, Van Dis ML. Odontogenic keratocysts: A clinical, radiographic and histopathologic study. Oral Surg Oral Med Oral Pathol 1988;66:145-53.

6. Stoelinga PJW, Bronkhorst FB. The incidence, multiple presentation and recurrence of aggressive cysts of the jaws. 1988;16:J Cranio-

7. Max-Fac Surg184-95. 
8. Ahlfors E, Larsson A, Sjögren S. The odontogenic keratocyst: A benign cystic tumor?. J Oral Maxillofac Surg 1984;42:10-9.

9. Neville BW, Dam DD, Allen CM, Bouquot JE. Oral and Maxillofacial. 2009;3rdPhiladelphia: WB Saunders683-.

10. Hjorting-Hansen E, Andreasen JO, Robinson LH. A study of odontogenic cysts with special reference to location of keratocysts. Br J Oral Surg 1969;7:15-23.

11. Wright JM. The odontogenic keratocyst: Orthokeratinized variant.Oral Surg 1981;51:609-18.

12. Chirapathomsakul D, Sastravaha P, Jansisyanont P. A review of odontogenic keratocysts and the behavior of recurrences. Oral Surg Oral Med Oral Pathol Oral Radiol Endod 2006;101:5-9.

13. Brannon RB. The odontogenic keratocyst. A clinicopathologicstudy of 312 cases. Part 1 . Clinical features. Oral Surg Oral Med Oral Pathol 1976;42:54-72.

14. Stoelinga PJ. Long-term follow-up on keratocysts treated according to a defined protocol. Int J Oral Maxillofac Surg 2001;30:14-25. 